\title{
OXIDATIVE STRESS AND GENETIC DIFFERENTIATION IN EXPERIMENTAL TILAPIA FISH EXPOSED TO HEAVY METALS IN A RESERVOIR NEAR A MUNICIPAL LANDFILL
}

\author{
KAMOLLERD, C. ${ }^{1,2}$ - SenAPHAN, K..$^{1,2}$ - TengJaroenKul, B. ${ }^{1,2}$ - MONKHEANG, P. ${ }^{1,3}$ \\ NEERATANAPHAN, L. ${ }^{1,3^{*}}$ \\ ${ }^{1}$ Research Group on Toxic Substances in Livestock and Aquatic Animals, Khon Kaen \\ University, Khon Kaen, Thailand \\ ${ }^{2}$ Faculty of Veterinary Medicine, Khon Kaen University, Khon Kaen, Thailand \\ ${ }^{3}$ Faculty of Science, Khon Kaen University, Khon Kaen, Thailand \\ *Corresponding author \\ e-mail:hlamya@kku.ac.th
}

(Received $18^{\text {th }}$ May 2019; accepted $28^{\text {th }}$ Aug 2019)

\begin{abstract}
This study aimed to investigate the concentrations of $\mathrm{Cd}, \mathrm{Cr}$ and $\mathrm{Pb}$ in the water and sediment, and to compare the concentrations of these metals in fish muscles, the levels of plasma oxidative stress biomarkers (malondialdehyde and protein carbonyl) and the genetic differentiation between experimental tilapia fish from the contaminated reservoir near municipal landfill and the reference area after chronic exposure to the metals. The concentrations of $\mathrm{Cd}, \mathrm{Cr}$ and $\mathrm{Pb}$ in the water exceeded the Thailand water quality standard, whereas the concentration of $\mathrm{Cd}$ in the sediment exceeded the Thailand soil quality standard. The concentrations of these metals in fish muscles were below Thailand food quality standard. In comparison to the reference fish, the fish in the landfill reservoir revealed a significant increase in malondialdehyde and protein carbonyl $(\mathrm{p}<0.05)$. The dendrogram results demonstrated values of genetic similarity for the fish from the reference and the landfill areas at 0.84-0.94 and 0.65-0.97, respectively, implying that the values of genetic differentiation as a consequence of genotoxicity of the fish from the landfill were greater than those of the fish from the reference area. The results indicate that chronic heavy metal exposure could induce oxidative stress and genotoxicity of tilapia fish in the reservoir near municipal landfill.
\end{abstract}

Keywords: oxidative stress, genetic differentiation, heavy metal, tilapia fish, municipal landfill

\section{Introduction}

In the past few decades, industrial, commercial and urban communities have continuously and rapidly grown in Khon Kaen Province, Thailand (PCD, 2014). This growth has inevitably been accompanied by rapid increases in municipal and industrial solid wastes. Due to poor management of landfill waste, toxic leachate that can spread heavy metals and other toxic substances around the landfill environment is present (Papadimitriou and Loumbourdis, 2003). The major heavy metals found in the Khon Kaen municipal landfill were cadmium $(\mathrm{Cd})$, chromium $(\mathrm{Cr})$, lead $(\mathrm{Pb})$ and arsenic $(\mathrm{As})$ (Sarun, 2004; Sriuttha et al., 2017; Intamat et al., 2017). Sriuttha et al. (2017) demonstrated that concentrations of $\mathrm{Cd}, \mathrm{Cr}$ and $\mathrm{Pb}$ in the water and sediment near the municipal landfill were as not detected, $0.016 \pm 0.009,0.009 \pm 0.0006 \mathrm{mg} / \mathrm{L}$ and $0.47 \pm 0.23,19.91 \pm 0.96,5.40 \pm 0.13 \mathrm{mg} / \mathrm{kg}$, respectively, while Intamat et al. (2017) determined that As values in the water, sediment and tilapia fish in the landfill environment were $0.006 \pm 0.002,1.08 \pm 0.64$ and $0.16 \pm 0.16 \mathrm{mg} / \mathrm{kg}$, respectively. From previous reports, these toxic metals can always spread from hazardous waste such as 
batteries, light bulbs, chemical containers and lubricants, into leachate and surrounding reservoirs (Oost et al., 2003; ATSDR, 2007), and can be taken up and accumulate in aquatic organisms, including fish (Luoma and Rainbow, 2008). Intamat et al. (2017) revealed that the As concentrations in Oreochromis niloticus, Barbonymus gonionotus, Rasbora tornieri and Anabas testudineus exceeded Thailand food quality standards. Sriuttha et al. (2017) found that the Cd concentrations in O. niloticus and B. gonionotus exceeded the limit of International standard for fish, additionally the $\mathrm{Cr}$ concentration in $R$. tornieri and $A$. testudineus exceeded the International standard, and the $\mathrm{Pb}$ concentration in all four fish species exceeded the International standards. Fish that inhabit heavy metal-contaminated reservoirs generally take in toxic metals by absorbing metals through their skin, gills and alimentary tracts (Kamunde et al., 2002; Papadimitriou and Loumbourdis, 2003; Robinson et al., 2003) and can demonstrate biomagnification, and these contaminated fish can result in health risks to consumers (Godt et al., 2006).

Several research studies have demonstrated that heavy metals can cause an imbalance between the production and reduction of free radical species, i.e., causing oxidative stress in fish (Livingstone, 2003; Sevcikova et al., 2011). The free radicals can attack protein and lipid molecules to induce oxidative stress products as well as cause negative consequences such as increases in malondialdehyde and protein carbonyl as well as fragmentation of deoxyribonucleic acid (DNA) (Castano and Becerril, 2004; Talas et al., 2008; Velma and Tchounwou, 2013; Vilela et al., 2018). Recently, the amount and diversified species of oxidative stress products have been considered biomarkers for environmental monitoring indices in terms of both status and situation of aquatic ecosystems (Skorbiłowicz, 2009; Burlibasa and Gavrila, 2011; Webb, 2011; Authman et al., 2015). The consequences of oxidative stress from toxic metals to aquatic animals have been reported, but information on their effects on fish with either acute or chronic exposure time in landfill ecosystems is limited. Therefore, the objectives of this study were to investigate heavy metal accumulation in a landfill reservoir, and to compare oxidative stress biomarkers as well as genetic differentiation between the experimental tilapia fish (Oreochromis niloticus) from the contaminated reservoir near municipal landfill and the reference area after chronic exposure to the metals.

\section{Materials and methods}

\section{Study site}

The study site was a reservoir located approximately 100 meters from the municipal landfill, Maung District, Khon Kaen Province, Thailand at latitude $16^{\circ} 35^{\prime} 41.30^{\prime \prime} \mathrm{N}$ and longitude $102^{\circ} 48^{\prime} 12.11^{\prime \prime} \mathrm{E}$ (Fig. 1). Geographic coordinate is UTM 48Q N 1,835,718 E 266,085 at a height of $200 \mathrm{~m}$ from the sea level.

\section{Fish and experimental design}

Juvenile tilapia fish at an average weight of 10.3 grams were reared at a density of $20 \mathrm{fish} / \mathrm{m}^{2}$ in $2 \times 2 \mathrm{~m}$ floating cages in the reservoir that received metal-contaminated leachate from the Khon Kaen municipal landfill. The experimental fish were randomly allocated into 2 treatments (reference and landfill) with 3 replications of each treatment, and they were fed a commercial pellet diet (Charoen Pokphan Co., Thailand) at 10\% 
w/w, 3 times/day for 4 months during April-July 2018 simulating the length of the tilapia production as in general practice. At the end of the experiment, fish muscles were measured for heavy metal accumulation, blood was collected from the caudal vessels for the plasma oxidative stress test, and the gills and livers were excised for the DNA study and genetic differentiation analysis. The control fish were collected from the Khon Kaen Inland Fisheries Research and Development Center, Thailand. Aquaculture in the Department of Fisheries is non-affected heavy metal contamination which has control of contamination for human food. Therefore, the control fish of this study is expected to not receive heavy metals.

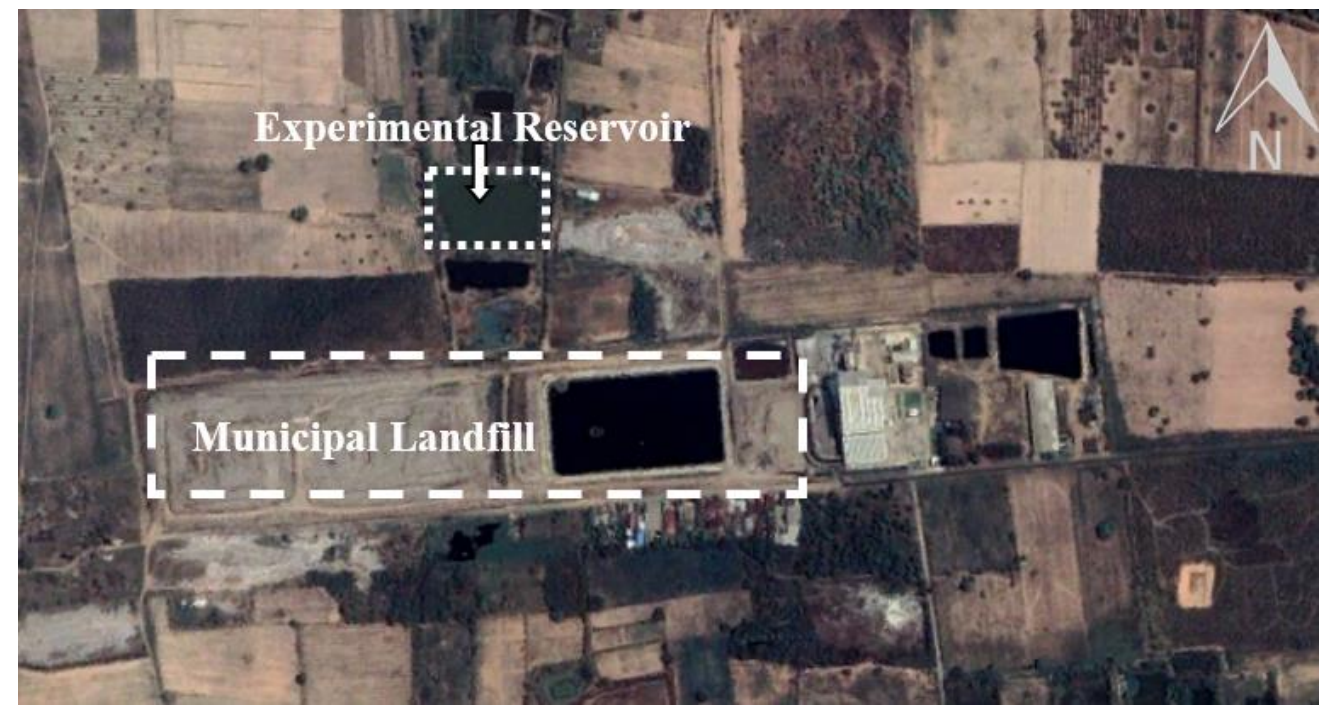

Figure 1. Overview of the municipal landfill and the location of the contaminated reservoir

\section{Water quality parameters}

Temperature, dissolved oxygen, $\mathrm{pH}$, total dissolved solids and electro-conductivity were measured at the sampling site using digital mobile meters. Total ammonia nitrogen was measured using the titration method (APHA, 2005) (Table 1).

Table 1. Methods used for analyses of water quality parameters

\begin{tabular}{l|l}
\hline \multicolumn{1}{c|}{ Water quality parameters } & \multicolumn{1}{c}{ Analysis methods } \\
\hline Temperature & Thermometer \\
Dissolved oxygen & DO meter, model 966, Mettler Toledo \\
$\mathrm{pH}$ & $\mathrm{pH}$ meter, model EcoScan pH 5, Eutech \\
Total dissolved solid & Total dissolved solid, model CH-8603, Mettler Toledo \\
Electro-conductivity & EC meter, model CH-8603, Mettler Toledo \\
Total ammonia nitrogen & Titration method \\
\hline
\end{tabular}

\section{Heavy metal measurements}

The water samples were acidified in the field by adding concentrated nitric acid until the $\mathrm{pH}$ was less than 2, the sediment samples were wrapped in aluminum foil to prevent oxidation, and the live fish were put into oxygenated plastic bags. All collected samples 
were digested following EPA method 6010, and the $\mathrm{Cd}, \mathrm{Cr}$ and $\mathrm{Pb}$ concentrations were analyzed using inductively coupled plasma optical emission spectrometry (ICP-OES) (Chand and Prasad, 2013; Neeratanaphan et al., 2017). The detection limits of each analyzed element were as follows: $\mathrm{Cd}$ and $\mathrm{Cr}: 0.001 \mathrm{mg} / \mathrm{kg}$ and $\mathrm{Pb}: 0.005 \mathrm{mg} / \mathrm{kg}$. The ICP-OES wavelengths for the $\mathrm{Cd}, \mathrm{Cr}$ and $\mathrm{Pb}$ analyses were set to $188.979,226.502$ and $267.716 \mathrm{~nm}$, respectively.

The analysis of blanks and quality control standards was performed after every $10^{\text {th }}$ sample. The concentrations of the elements in the procedural blanks were typically $<5 \%$ of the mean analyzed concentrations for all the heavy metals. Replicate analyses and standard reference materials were used to guarantee the precision and accuracy of the measurements for all elements. The results were found not to deviate by more than $2 \%$ of the certified values, indicating the accuracy of the analysis (APHA, 2005). The heavy metal recovery values were calculated by acceptance criteria in the range of $85-115 \%$ (USEPA, 2000). The results were $90-100 \%$ of the acceptable values and considered accurate.

\section{Oxidative stress biomarkers}

After being reared for 4 months in the landfill reservoir, the blood plasma of the experimental fish were collected at the reservoir site to determine malondialdehyde (MDA) by measuring thiobarbituric acid reactive substances (Luangaram et al., 2007; Nakmareong et al., 2011) and to measure protein carbonyl (PC) by its reaction with 2,4dinitrophenylhydrazine (Reznick and Packer, 1994; Nakmareong et al., 2011). For the genotoxicity study, DNA from the livers and gills of the fish were extracted and amplified by 46 inter-simple sequence repeats (ISSR) primers (Table 2) in a PCR thermal cycler (Flex Cycler ${ }^{2}$, Analytikjena) (Tengjaroenkul et al., 2018). Each DNA band was evaluated and recorded as the following diallelic characters as present $=1$ and absent $=0$. All of the bands were imported to construct dendrogram by the NTSYSpc 2.1 program (Rohlf, 2009) for analysis of genetic differentiation as a consequence of genotoxicity.

\section{Statistical analyses}

Statistical analyses of the oxidative stress biomarkers in experimental and control fish were analysed using the Mann-Whitney U-test. The genetic differentiation was analyzed to construct dendrogram by the NTSYSpc 2.1 program (Rohlf, 2009). All of the statistical tests were conducted at a $95 \%$ confidence level.

\section{Results and discussion}

\section{Water quality parameters}

The water quality parameters of the reference and the landfill reservoir water samples after 4 months of the experiment are shown in Table 3.

Water quality describes conditions of water medium and its related suitability to sustainably support aquatic ecosystems as well as public health. Low water quality could influence the stress, metabolism, health, reproduction, genetics and biodiversity of fish (Jezierka and Witeska, 2001; Buet et al., 2006; Da Rocha et al., 2009). In this study, the water quality parameters from both the reference and the landfill reservoirs were within the Thailand standard concentration limits for surface water sources (Ip et 
al., 2001; PCD, 2014); therefore, plasma oxidative stress and genotoxicity biomarkers in long-term experimental tilapia tended to have fewer effects from the water quality parameters in both areas.

\section{Heavy metal concentrations}

The heavy metal concentrations in the water, sediment and fish muscles from the reservoir near the municipal landfill are shown in Table 4.

Table 2. The 24 successful primer sequences for ISSR fingerprinting

\begin{tabular}{|c|c|c|c|c|}
\hline Primer & Nucleotide sequences & Total bands & Monomorphic band & Polymorphic band \\
\hline P1 & AGAGAGAGAGAGAGAGG & 127 & 7 & 10 \\
\hline P3 & СТСТСТСТСТСТСТСТGС & 100 & 3 & 12 \\
\hline $\mathrm{P} 4$ & CACACACACACAAC & 54 & 4 & 5 \\
\hline P5 & CACACACACACAGT & 101 & 3 & 11 \\
\hline P6 & CACACACACACAAG & 77 & 4 & 9 \\
\hline P7 & CACACACACACAGG & 127 & 7 & 11 \\
\hline P8 & GAGAGAGAGAGAGG & 102 & 7 & 6 \\
\hline P10 & GAGAGAGAGAGACC & 126 & 3 & 17 \\
\hline P11 & GTGTGTGTGTGTCC & 51 & 4 & 3 \\
\hline P12 & CACCACCACGC & 119 & 6 & 9 \\
\hline P13 & GAGGAGGAGGC & 117 & 7 & 8 \\
\hline P14 & CTCCTCCTCGC & 111 & 3 & 14 \\
\hline P15 & GTGGTGGTGGC & 116 & 8 & 8 \\
\hline P16 & ACTGACTGACTGACTG & 113 & 8 & 7 \\
\hline P17 & GACAGACAGACAGACA & 81 & 2 & 13 \\
\hline I1 & СТСТСТСТСТСТСТСТTG & 99 & 2 & 15 \\
\hline $\mathrm{I} 2$ & AGAGAGAGAGAGAGCTGCT & 127 & 7 & 9 \\
\hline A4 & AGAGAGAGAGAGAGAA & 118 & 6 & 14 \\
\hline A5 & AGAGAGAGAGAGAGAGC & 142 & 10 & 7 \\
\hline A6 & AGAGAGAGAGAGAGAGT & 114 & 4 & 18 \\
\hline A11 & AGAGAGAGAGAGAGAAA & 108 & 3 & 13 \\
\hline A12 & AGAGAGAGAGAGAGAAC & 126 & 8 & 9 \\
\hline A13 & AGAGAGAGAGAGAGAAG & 118 & 9 & 7 \\
\hline \multirow[t]{2}{*}{ A14 } & AGAGAGAGAGAGAGAAT & 88 & 3 & 10 \\
\hline & Total & 2,562 & 128 & 245 \\
\hline
\end{tabular}

Table 3. Water quality parameters (temperature, dissolved oxygen, $p H$, total dissolved solids, electro-conductivity and total ammonia nitrogen) of the reference and the landfill reservoir

\begin{tabular}{c|c|c|c|c|c|c}
\hline \multirow{2}{*}{ Samples } & \multicolumn{6}{|c}{ Parameters } \\
\cline { 2 - 7 } & $\begin{array}{c}\text { Temperature } \\
\left({ }^{\circ} \mathbf{C}\right)\end{array}$ & $\begin{array}{c}\text { DO } \\
(\mathbf{m g} / \mathbf{L})\end{array}$ & $\mathbf{p H}$ & $\begin{array}{c}\mathbf{T D S} \\
(\mathbf{m g} / \mathbf{L})\end{array}$ & $\begin{array}{c}\mathbf{E C} \\
\left(\boldsymbol{\mu S S m} \mathbf{S m}^{-1} / \mathbf{s}\right)\end{array}$ & $\begin{array}{c}\mathbf{N H}-\mathbf{N} \\
(\mathbf{m g} / \mathbf{L})\end{array}$ \\
\hline Reference reservoir & $25.96 \pm 0.55$ & $5.31 \pm 0.76$ & $7.02 \pm 0.02$ & $0.44 \pm 0.03$ & $304.33 \pm 7.37$ & $0.72 \pm 0.04$ \\
Landfill reservoir & $26.18 \pm 0.53$ & $4.79 \pm 0.44$ & $6.72 \pm 0.07$ & $0.57 \pm 0.03$ & $452.67 \pm 17.51$ & $0.94 \pm 0.04$ \\
\hline
\end{tabular}

$\mathrm{DO}=$ dissolved oxygen; TDS = total dissolved solids; $\mathrm{EC}=$ electro-conductivity $; \mathrm{NH}_{3}-\mathrm{N}=$ total ammonia nitrogen; $\mathrm{n}$ (numbers of measured individuals) $=3$ 
Table 4. Heavy metal concentrations in the water, sediment and fish muscles from the landfill reservoir (mean and standard deviation; $n=9$ )

\begin{tabular}{l|c|c|c|c}
\hline \multicolumn{1}{c|}{ Samples } & Individual number & Cd & $\mathbf{C r}$ & $\mathbf{P b}$ \\
\hline Water $(\mathrm{mg} / \mathrm{L})$ & 9 & $0.66 \pm 0.32$ & $16.73 \pm 1.32$ & $17.85 \pm 4.28$ \\
Standard $(\mathrm{mg} / \mathrm{L})$ & & $0.005^{\mathrm{a}}$ & $0.05^{\mathrm{a}}$ & $0.05^{\mathrm{a}}$ \\
Sediment $(\mathrm{mg} / \mathrm{kg})$ & 9 & $2.60 \pm 2.07$ & $33.82 \pm 7.79$ & $16.61 \pm 9.47$ \\
Standard $(\mathrm{mg} / \mathrm{kg})$ & & $1^{\mathrm{b}}$ & $100^{\mathrm{b}}$ & $100^{\mathrm{b}}$ \\
Fish muscle $(\mathrm{mg} / \mathrm{kg})$ & 9 & $0.02 \pm 0.01$ & $1.22 \pm 0.29$ & $0.10 \pm 0.02$ \\
Standard $(\mathrm{mg} / \mathrm{kg})$ & & $0.5^{\mathrm{c}}$ & $2^{\mathrm{c}}$ & $0.5^{\mathrm{c}}$ \\
\hline
\end{tabular}

${ }^{a}$ Water quality standards for surface water sources, Pollution Control Department, Ministry of Natural Resources and Environment, Thailand (PCD, 1994)

${ }^{b}$ Soil quality standard, Pollution Control Department, Ministry of Natural Resources and Environment, Thailand (PCD, 2004)

'Thailand food quality standards, Ministry of Public Health, Thailand (Ministry of Public Health, 2003)

The concentrations of $\mathrm{Cd}, \mathrm{Cr}$ and $\mathrm{Pb}$ in the water exceeded the Thailand water quality standards for surface water sources (PCD, 1994), whereas the concentration of Cd exceeded the Thailand soil quality standard (PCD, 2014). The concentrations of the metals in the fish muscles were below those of Thailand food quality standards (Ministry of Public Health, 2003). Waste segregation and management in the Khon Kaen municipal landfill were not appropriate, resulting in the disposal of municipal waste and hazardous waste, which can be potential sources of heavy metal exposure in fish (Sarun, 2004). As in other polluted areas, heavy metal contamination in the Khon Kaen landfill leachate can lead to metal accumulation in the soil and sediment of the reservoir, and can then be absorbed and accumulated into aquatic plants and animals (Luoma and Rainbow, 2008). These bioaccumulation processes were identified by the studies of Promsid (2014): and Intamat et al. (2017): who found heavy metal accumulation in plants and animals in the reservoir, especially emerged plants (Limnocharis flava, Diplasum esculentum and Nymphea lotus) and aquatic animals such as Monopterus albus, Clarias batrachus and Channa striata. Intamat et al. (2017) revealed that As in Oreochromis niloticus, Barbonymus gonionotus, Rasbora tornieri and Anabas testudineus exceeded the Thailand food quality standard. Sriuttha et al. (2017) found that the Cd concentration in O. niloticus and B. gonionotus exceeded the limit in the International standards for fish (FAO, USA), whereas the $\mathrm{Cr}$ concentration in $R$. tornieri and A. testudineus exceeded the limits in the International standards, and the $\mathrm{Pb}$ concentration in four fish species exceeded the limit in the International standards. Furthermore, this study investigated the $\mathrm{Cd}, \mathrm{Cr}$ and $\mathrm{Pb}$ concentrations in the tilapia as the major commercialized fish consumed throughout local communities in Khon Kaen Province. Generally, tilapia fish culture in Thailand of 4 months was the model condition that simulated the practice. As the experimental tilapia fish had a relatively long exposure period of 4 months, they could continuously accumulate heavy metals from water and sediments into their organs (Chen and Liao, 2004; Cumberlidge, 2009; Abdulali et al., 2013; Abdel-mohsien and Mahmoud, 2015). This continuous accumulation in the tilapias occurs probably because they have a large body size and surface area with the contaminated environment. In accordance with several reports, chronic exposure of $\mathrm{Cd}, \mathrm{Cr}$ and $\mathrm{Pb}$ to experimental tilapia fish may lead to stress, metabolic changes, physical damage and hematological, hepatological, and immunological alterations (Mishra and Mohanty, 2008; Paul et al., 2014; Pereira et al., 
2016). Furthermore, after consumption, a fish that has accumulated heavy metals can do harm to humans in surrounding communities by causing detrimental diseases and disorders related to these metals (Godt et al., 2006; Tiwari et al., 2011). In general, the levels and potential of risk from the accumulated metals in the fish in the landfill reservoir to consumer health depend on several factors, including speciation, dose, time and toxicokinetics of the heavy metals contained in the exposed animals (Abu-Daabes et al., 2013; Wachirawongsakorn and Sangyoka, 2013).

\section{Oxidative stress biomarkers}

\section{Malondialdehyde}

Levels of plasma MDA in the tilapia fish are shown in Figure 2. In comparison with the reference fish, the fish from the reservoir near the Khon Kaen municipal landfill demonstrated a significant increase in plasma MDA $(p<0.05)$.

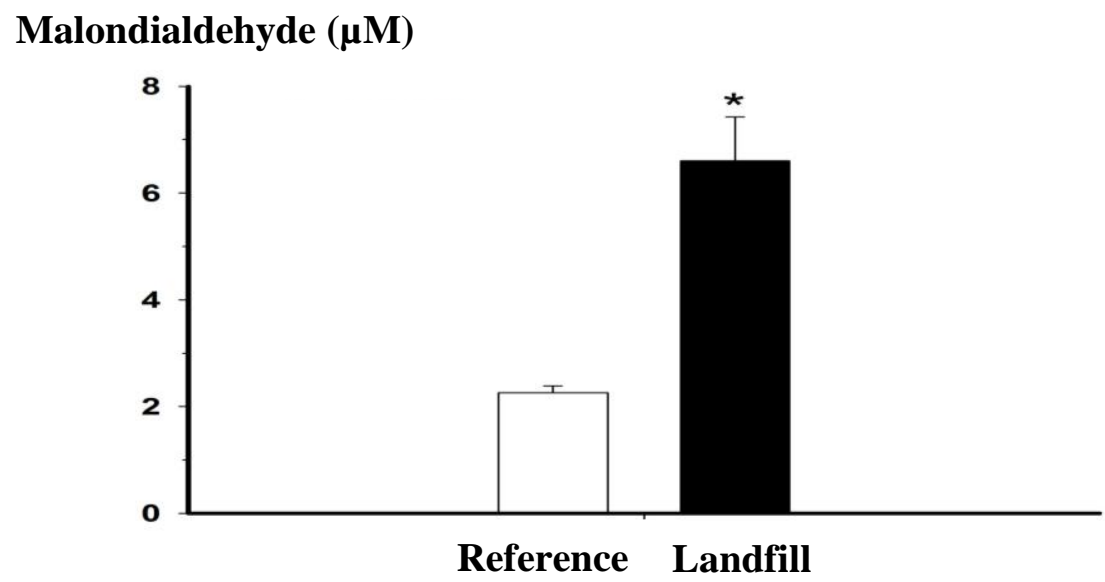

Figure 2. The levels of plasma malondialdehyde in both treatments of the Nile tilapia fish. Values are expressed as the mean \pm SEM of 10 fish. ${ }^{*} p<0.05$ compared with the reference fish

Contaminated landfill leachate as well as reservoir water and sediments usually contain complex mixtures of heavy metals capable of accumulating in aquatic organisms (Luoma and Rainbow, 2008). Heavy metals can induce reactive oxygen and nitrogen species, i.e., causing oxidative stress or free radical overload in aquatic organisms, including fish (Sevcikova et al., 2011). Assessments of oxidative damage in fish can directly reflect metal exposure in an aquatic environment, which could affect the health of the creatures (Livingstone, 2003). Contaminated heavy metals in living fish generally interact with nuclear proteins, lipid molecules and nuclear nucleic acids, resulting increases in MDA and PC and fragmentation of DNA strands (Livingstone, 2003; Sevcikova et al., 2011).

MDA is one of the lipid peroxidation products derived from oxidative attacks on cell membrane phospholipids and circulating lipids, and its increased level directly involves the degree of oxidative damage induced by the contaminants, including heavy metals (Banerjee et al., 1999; Ercal et al., 2001). A measure of MDA content provides the relative consequence of the potential for pollutants to cause oxidative injury (Vlahogianni et al., 2007; Calapoglu et al., 2017). In this study, a significant increase in plasma MDA concentration was found in the tilapia fish, indicating that the presence of heavy metals could cause oxidative stress as well as negative effects on cell homeostasis such as protein 
metabolism, glutathione pathways and mitochondrial functions. Several other reports revealed similar results related to increases MDA in fish, including killifish, mullet, flounder, catfish and stickleback, after exposure to pollutants (Bakanskas et al., 2004; Ferreira et al., 2005; Farombi et al., 2007; Sanchez et al., 2007; Bayir et al., 2011).

\section{Protein carbonyl}

The levels of plasma PC in the tilapia fish are shown in Figure 3. In comparison with the reference fish, the fish from the reservoir near the landfill area demonstrated a significant increase in plasma PC $(\mathrm{p}<0.05)$.

\section{Protein Carbonyl}

(nmol/mg Protein)

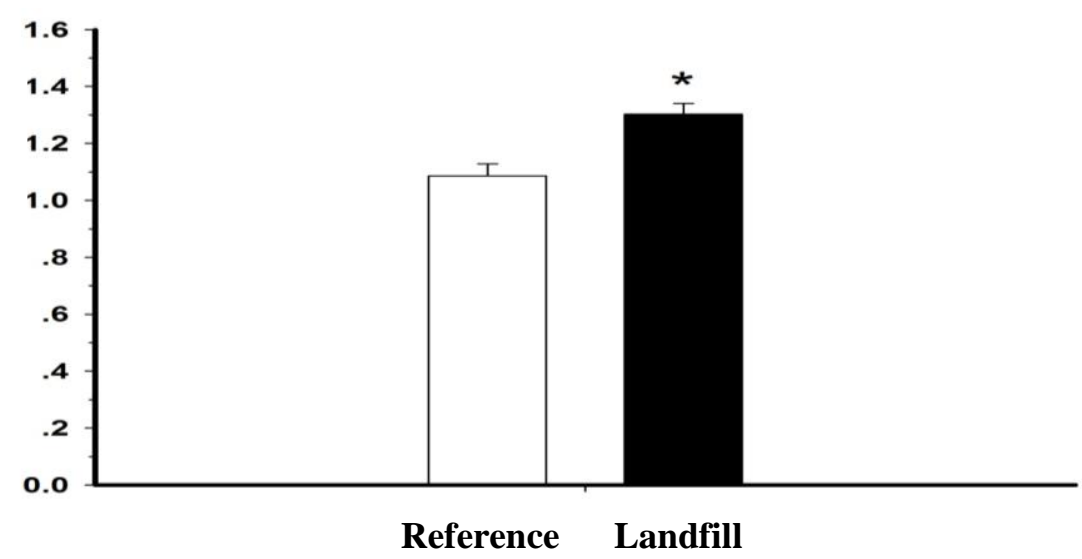

Figure 3. The levels of plasma protein carbonyl in both groups of the Nile tilapia fish. Values are expressed as the mean \pm SEM of 10 fish. ${ }^{*} p<0.05$ as compared with the reference fish

PC formation can occur as a result of oxidative stress, and has been shown as a number of tissue lesions and disease issues (Requena et al., 2003). An increase in the number of carbonyl groups correlates well with protein damage caused by oxidative stress; therefore, PC can be a distinctive marker to induce the degradation of enzymes, to change amino acid structures and to alter protein functions (Grune, 2000; Parvez and Raisuddin, 2005; Dalle-Donne et al., 2006; Craig et al., 2007). In accordance with previous reports, the elevated level of PC in the Nile tilapia from the landfill reservoir could suggest that metal pollutants may cause protein damage as a consequence of oxidative stress. Furthermore, the significant increase in oxidative stress biomarkers in tilapia fish may be associated with a low resistance to pollution in this fish. To present, responses to oxidative stress in fish have been recorded differently according to habitat and feeding behavior of fish as well as concentrations and types of the pollutants (Giulio et al., 1993; Wilhelm, 1996; Hebert et al., 2008).

\section{$D N A$}

The 24 ISSR primers were successfully applied to generate 2,562 total bands with 375 characteristics, including 128 similar band profiles and 245 different band profiles. The dendrogram separated tilapia fish into two clusters corresponding to their studied areas. The genetic similarity values of the fish in the contaminated reservoir near municipal 
landfill (Fish No. 2.1, 2.2, 2.3, 2.4 and 2.5) ranged from 0.65 to 0.97, and the values for the fish from the reference area (Fish No. 1.1, 1.2, 1.3, 1.4 and 1.5) (Table 5; Figs. 4-5) ranged from 0.84 to 0.94 .

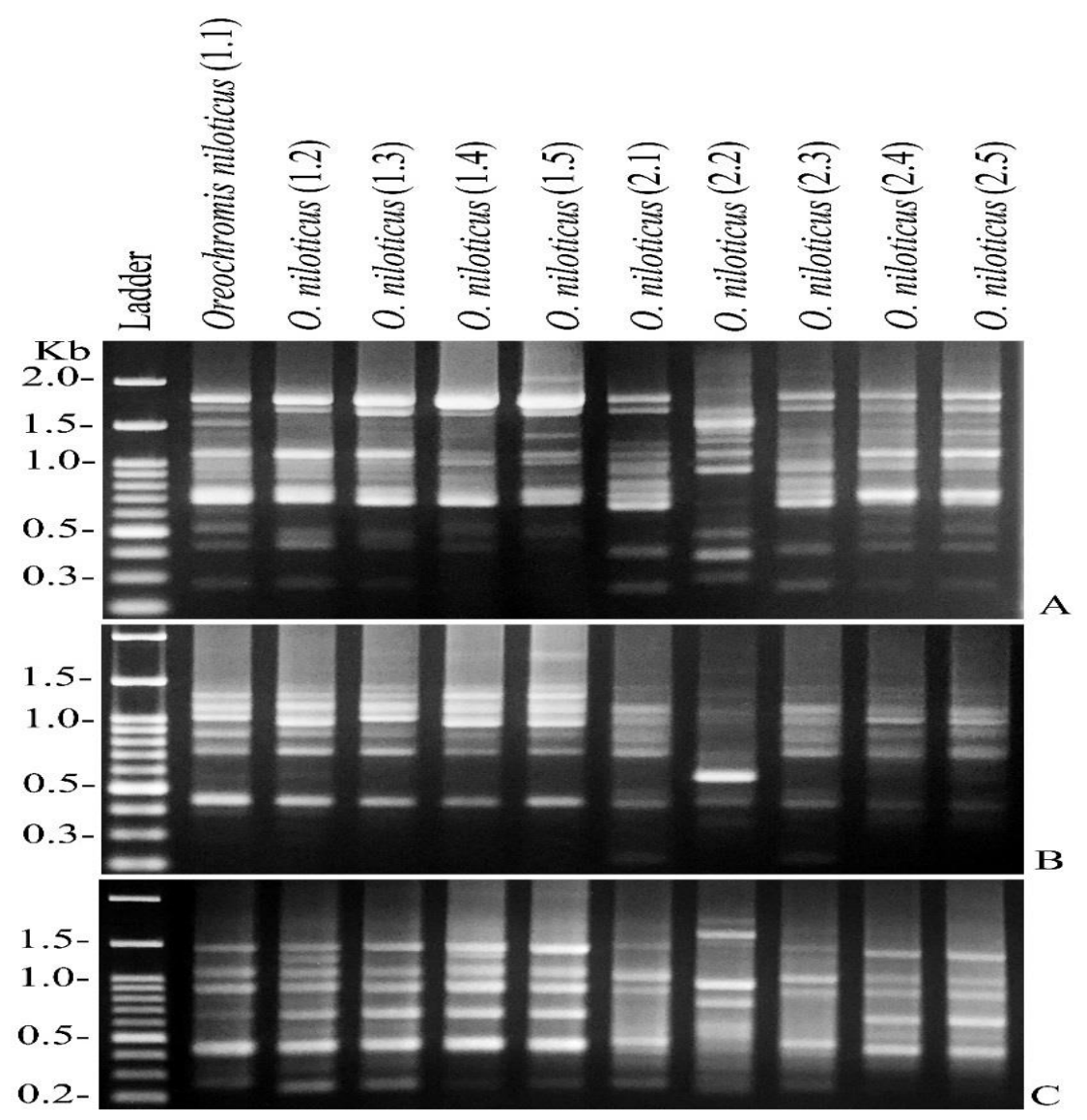

Figure 4. Examples of ISSR fingerprints from the reference fish $(1.1,1.2,1.3,1.4$, and 1.5) and the contaminated reservoir near a municipal landfill (2.1, 2.2, 2.3, 2.4, and 2.5) from the specific primers TGACCCCTCC (a), GTAGACGAGC (b) and TGTCTGGGTG (c) showing monomorphic bands

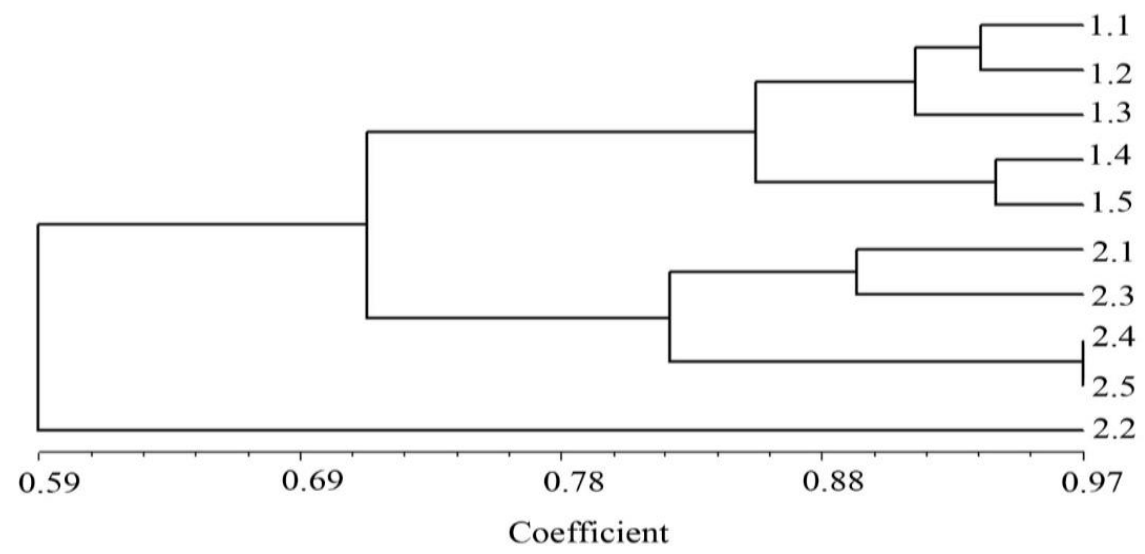

Figure 5. The dendrogram constructed from 24 ISSR primers by the NTSYSpc 2.1 program showing the genetic relationships of the tilapia fish from the reference area and the contaminated reservoir near a municipal landfill 
Table 5. Values of genetic similarity between the tilapia fish from the reference and the contaminated reservoir near municipal landfill using NTSYSpc 2.1 program

\begin{tabular}{c|c|c|c|c|c|c|c|c|c|c}
\hline Fish No. & $\mathbf{1 . 1}$ & $\mathbf{1 . 2}$ & $\mathbf{1 . 3}$ & $\mathbf{1 . 4}$ & $\mathbf{1 . 5}$ & $\mathbf{2 . 1}$ & $\mathbf{2 . 2}$ & $\mathbf{2 . 3}$ & $\mathbf{2 . 4}$ & $\mathbf{2 . 5}$ \\
\hline 1.1 & 1.00 & & & & & & & & & \\
1.2 & 0.94 & 1.00 & & & & & & & & \\
1.3 & 0.92 & 0.90 & 1.00 & & & & & & & \\
1.4 & 0.84 & 0.86 & 0.87 & 1.00 & & & & & & \\
1.5 & 0.85 & 0.84 & 0.87 & 0.94 & 1.00 & & & & & \\
2.1 & 0.72 & 0.73 & 0.71 & 0.68 & 0.69 & 1.00 & & & & \\
2.2 & 0.55 & 0.57 & 0.53 & 0.52 & 0.52 & 0.65 & 1.00 & & & \\
2.3 & 0.73 & 0.73 & 0.73 & 0.68 & 0.69 & 0.89 & 0.66 & 1.00 & & \\
2.4 & 0.73 & 0.74 & 0.71 & 0.67 & 0.67 & 0.80 & 0.65 & 0.84 & 1.00 & \\
2.5 & 0.75 & 0.75 & 0.72 & 0.68 & 0.68 & 0.80 & 0.66 & 0.84 & 0.97 & 1.00 \\
\hline
\end{tabular}

The results from the dendrogram analyses separated the tilapia into two clusters corresponding to their studied areas. The genetic differentiation in tilapia fish revealed a positive correlation with $\mathrm{Cd}, \mathrm{Cr}$ and $\mathrm{Pb}$ concentrations accumulated in the fish body. The genetic differentiation in the fish from the contaminated reservoir near the landfill was greater than that of the fish from the reference area. These findings suggested that the metal accumulations in the landfill fish could affect the genetic toxicity in term of the molecular nucleic acid profile. In contaminated environments, heavy metal exposure could demonstrate DNA damage in fish as single and double strand breakages, alterations in DNA repair processes, oxidation of nucleic bases and DNA-protein crosslinks (Wood et al., 2001; Monserrat et al., 2007; Vilela et al., 2018). When heavy metals enter the cell membrane, they generally induce diversified genotoxicity through several mechanisms. For example, Cd can induce oxidative stress, DNA damage, point mutations, mutagenesis, deletions, ploidy changes, substitutions and oxidization in gene bases (Waalkes, 2003; Castano and Becerril, 2004; Suhartono et al., 2013). Cr exposure demonstrated micronucleus appearance, Cr-DNA adducts, DNA strand breakage, protein-Cr-DNA adducts and modification of the DNA nitrogenous base, leading to neoplastic growth in fish (Teles et al., 2005; Wise et al., 2008; Arunachalam et al., 2013; Velma and Tchounwou, 2013). Pb can induce oxidative damage, mitogenesis, alteration in gene transcription, carcinogenic events involved in DNA damage and several other indirect genotoxic changes (Silbergeld, 2003). Furthermore, the loss of DNA structural or functional integrity in exposed organisms can initiate deleterious effects at both the individual and population levels, especially through impaired growth or reproduction (Bolognesi and Hayashi, 2011; Mustafa et al., 2012; Ngamniyom, 2012). Furthermore, experimental tilapia fish could be a potential bioindicator for genotoxicity in aquatic ecosystems. In addition, local communities around the municipal landfill should increase their awareness, and enhance environmental management to reduce the risks to human health from consuming the heavy metals accumulated in the fish from the landfill reservoir.

\section{Conclusion}

The concentrations of $\mathrm{Cd}, \mathrm{Cr}$ and $\mathrm{Pb}$ in $O$. niloticus after chronic exposure to heavy metals in a reservoir near municipal landfill for 4 months were below Thailand food 
quality standard for these metals. In comparison to the fish in the reference area, the fish in the landfill area demonstrated a significant increase in MDA and PC with a relatively greater genetic differentiation. The results of the study demonstrate that heavy metals potentially induce oxidative stress and genetic alteration in the tilapia fish in the reservoir near the municipal landfill. Future researches should be comparative study oxidative stress in the other aquatic animals in this area.

Acknowledgements. This research was supported by Khon Kaen University under the Incubation Researcher Project and the Research Group on Toxic Substances in Livestock and Aquatic Animals, Khon Kaen University, Thailand.

\section{REFERENCES}

[1] Abdel-mohsien, H., Mahmoud, M. (2015): Accumulation of some heavy metals in Oreochromis niloticus from the Nile in Egypt: potential hazards to fish and consumers. Journal of Environmental Protection 6(9): 1003-1013.

[2] Abdulali, T., Shuhaimi-Othman, M., Ahmad, A. K. (2013): Assessment of heavy metals in tilapia fish (Oreochromis niloticus) from the Langat River and engineering lake in Bangi, Malaysia, and evaluation of the health risk from tilapia consumption. Ecotoxicology and Environmental Safety 93: 45-51.

[3] Abu-Daabes, M., Qdais, H. A., Alsyouri, H. (2013): Assessment of heavy metals and organics in municipal solid waste leachates from landfills with different ages in Jordan. Journal of Environmental Protection 4: 344-352.

[4] Agency for Toxic Substances and Disease Registry (ATSDR) (2007): Toxicological Profile for Lead. - Agency for Toxic Substances and Disease Registry, Washington DC.

[5] American Public Health Association (APHA) (2005): Standard Methods for the Examination of Water and Wastewater. 21 ${ }^{\text {st }}$ Ed.- American Public Health Association, Washington DC.

[6] Arunachalam, K. D., Annamalai, S. K., KuruvaIn, J. K. (2013): In-vivo evaluation of hexavalent chromium induced DNA damage by alkaline comet assay and oxidative stress in Catla catla. - American Journal of Environmental Sciences 9(6): 470-482.

[7] Authman, M. M. N., Zaki, M. S., Khallaf, E. A., Abbas, H. H. (2015): Use of fish as bioindicator of the effects of heavy metals pollution. - Journal of Aquaculture Research and Development 6: 328.

[8] Bacanskas, L. R., Whitaker, J., Di, Giulio, R. T. (2004): Oxidative stress in two populations of killifish (Fundulus heteroclitus) with differing contaminant exposure histories. - Marine Environmental Research 58(2): 597-601.

[9] Banerjee, B. D., Seth, V., Bhattacharya, A., Pasha, S. T., Chakraborty, A. K. (1999): Biochemical effects of some pesticides on lipid peroxidation and free-radical scavengers. - Toxicology Letters 107: 33-47.

[10] Bayir, A., Bayir, M., Sirkecioğlu, A. N., Aras, N. M., Haliloğlu, H. İ., Aksakal, E., Güneş, M., Aras, N. M. (2011): Influence of season on antioxidant defense systems of Silurus glanis Linnaeus (Siluridae) and Barbus capito Güldenstädt (Cyprinidae). Fresenius Environmental Bulletin 20(1): 3-11.

[11] Bolognesi, C., Hayashi, M. (2011): Micronucleus assay in aquatic animals. Mutagenesis 26: 205-213.

[12] Buet, A., Banas, D., Vollaire, Y., Coulet, E., Roche, H. (2006): Biomarker responses in European eel (Anguilla anguilla) esposed to persistent organic pollutants. A field study in the Vaccares lagoon (Camargue, France). - Chemosphere 65: 1846-1858.

[13] Burlibasa, L., Gavrila, L. (2011): Amphibians as model organisms for study environmental genotoxicity. - Applied Ecology and Environmental Research 9(1): 1-15. 
[14] Calapoglu, M., Sevinc, Z., Togany, V. A., Kalyoncu, H. (2017): Evaluation of oxidative stress and genotoxicity for environmental monitoring using farmed rainbow trout. Fresenius Environmental Bulletin 26(12): 7105-7113.

[15] Castano, A., Becerril, C. (2004): In vitro assessment of DNA damage after short and long-term exposure to benzo (a) pyrene using RAPD and the RTG-2 fish cell line.Mutation Research 552: 141-151.

[16] Chand, V., Prasad, S. (2013): ICP-OES assessment of heavy metal contamination in tropical marine sediments: A comparative study of two digestion techniques. Microchemical 111: 53-56.

[17] Chen, B. C., Liao, C. M. (2004): Farmed tilapia Oreochromis mossambicus involved in transport and biouptake of arsenic in aquacultural ecosystems. - Aquaculture 242: 365380 .

[18] Cumberlidge, N., Ng, P. K. L., Yeo, D. C. J., Magalhaes, C., Campos, M. R., Alvarez, F., Naruse, T., Daniels, S. R., Esser, L. J., Attipoe, F. Y. K., Clotilde-Ba, F., Darwall, W., Mclvor, A., Baillie, J. E. M., Collen, B., Ram, M. (2009): Freshwater crabs and the biodiversity crisis importance, threats, status, and conservation challenges. - Biological Conservation 142: 665-1673.

[19] Craig, P. M., Wood, C. M., McClell, G. B. (2007): Oxidative stress response and gene expression with acute copper exposure in zebrafish (Danio rerio). - American Journal of Physiology-Regulatory, Integrative and Comparative Physiology 293: 1882-1892.

[20] Da Rocha, A. M., Salomao de Freitas, D. P., Burns, M., Vieira, J. P., de la Torre, F. R., Monserrat, J. M. (2009): Seasonal and organ variation in antioxidant capacity, detoxifying competence and oxidative damage in freshwater and estuarine fishes from southern Brazil. - Comparative Biochemistry and Physiology 150: 512-520.

[21] Dalle-Donne, I., Aldini, G., Carini, M., Colombo, R., Rossi, R., Milzani, A. (2006): Protein carbonylation, cellular dysfunction, and disease progression. - Journal of Cellular and Molecular Medicine 10(2): 389-406.

[22] Ercal, N., Gurer-Orhan, H., Aykin-Burns, N. (2001): Toxic metals and oxidative stress part I: mechanisms involved in metal-induced oxidative damage. - Current Topics in Medicinal Chemistry 1: 529-539.

[23] Farombi, E. O., Adelowo, O. A., Ajimoko, Y. R. (2007): Biomarkers of oxidative stress and heavy metal levels as indicators of environmental pollution in African Catfish (Clarias gariepinus) from Nigeria Ogun River. - International Journal of Environmental Research and Public Health 4(2): 158-165.

[24] Ferreira, M., Moradas-Ferreira, P., ReisHenriques, M. A. (2005): Oxidative stress biomarkers in two resident species, mullet (Mugil cephalus) and flounder (Platichthys flesus), from a polluted site in River Douro Estuary, Portugal. - Aquatic Toxicology 71(1): 39-48.

[25] Giulio, R. T. D., Habig, C., Gallagher, E. P. (1993): Effects of black rock harbor sediments on indices of biotransformation, oxidative stress, and DNA integrity in channel catfish. - Aquatic Toxicology 26: 1-22.

[26] Grune, T. (2000): Oxidative stress, aging and the proteasomal system. - Biogerontology 1(1): $31-40$.

[27] Godt, J., Scheigig, F., Grosse-Siestrup, C., Esche, V., Brandenburg, P., Reich, A., Groneberg, D. A. (2006): The toxicity of cadmium and resulting hazards for human health. - Journal of Occupational Medicine and Toxicology 1: 22.

[28] Hebert, N., Gagne, F., Cejka, P., Cyr, D., Marcogliese, D. J., Blaise, C., Pellerin, J., Fournier, M. (2008): The effects of a primary-treated municipal effluent on the immune system of rainbow trout (Oncorhynchus mykiss): exposure duration and contribution of suspended particles. - Comparative Biochemistry and Physiology Part C: Comparative Pharmacology 148(3): 258-264. 
[29] Intamat, S., Buasriyot, P., Sriuttha, M., Tengjaroenkul, B., Neeratanaphan, L. (2017): Bioaccumulation of arsenic in aquatic plants and animals near a municipal landfill. International Journal of Environmental Studies 74(2): 303-314.

[30] Ip, Y. K., Chew, S. F., Randall, D. J. (2001): Ammonia Toxicity, Tolerance and Excretion. - In: Hoar, W. S., Randall, D. J., Farrell, A. P. (eds.) Fish Physiology, Vol. 20. Nitrogen Excretion. Academic Press, San Diego, CA. pp. 109-148.

[31] Jezierska, B., Witeska, M. (2001): Metal toxicity to fish. - Reviews in Fish Biology and Fisheries 11(3): 279-279.

[32] Kamunde, C., Grosell, M., Higgs, D., Wood, C. M. (2002): Copper metabolism in actively growing rain bow trout (Oncorhynchus mykiss): Interactions between dietary and waterbone copper uptake. - Journal of Experimental Biology 205: 279-290.

[33] Livingstone, D. (2003): Oxidative stress in aquatic organism in relation to pollution and agriculture. - Revue de Medecine Veterinaire 154: 427-430.

[34] Luangaram, S., Kukongviriyapan, U., Pakdeechote, P., Kukongviriyapan, V., Pannangpetch, P. (2007): Protective effects of quercetin against phenylhydrazineinduced vascular dysfunction and oxidative stress in rats. - Food and Chemical Toxicology 45: 448-455.

[35] Luoma, S., Rainbow, P. (2008): Sources and Cycles of Trace Metals. In: Metal Contamination in Aquatic Environments: Science and Lateral Management. - Cambridge University Press, Cambridge.

[36] Ministry of Public Health (2003): Standard of Contaminants in Food. - Notification of the Ministry of Public Health No. 273/2, Bangkok, Thailand.

[37] Mishra, A. K., Mohanty, B. (2008): Acute toxicity impacts of hexavalent chromium on behavior and histopathology of gill, kidney and liver of the freshwater fish, Channa punctatus (Bloch). - Environmental Toxicology and Pharmacology 26: 136-141.

[38] Monserrat, J. M., Martinez, P. E., Geracitano, L., Amado, L. L., Martins, C., Pinho, G. L. L., Chaves, I. S., Cravo, M. F., Ventura-Lima. J., Biachini, A. (2007): Pollution biomarkers in estuarine animals: Critical review and new perspectives. - Comparative Biochemistry and Physiology Part C: Toxicology Pharmacology 146(1-2): 221-234.

[39] Mustafa, S., Widodo, M. A., Kristianto, Y. (2012): Albumin and zinc content of snakehead fish (Channa striata) extract and its role in health. - International Journal of Science and Technology 1: 1-18.

[40] Nakmareong, S., Kukongviriyapan, U., Pakdeechote, P., Donpunha, W., Kukongviriyapan, V., Kongyingyoes, B., Sompamit, K., Phisalaphong, C. (2011): Antioxidant and vascular protective effects of curcumin and tetrahydrocurcumin in rats with L-NAME-induced hypertension. - Naunyn-Schmiedeberg's Archives of Pharmacology 383: 519-529.

[41] Neeratanaphan, L., Khamlerd, C., Chowrong, S., Intamat, S., Sriuttha, M., Tengjaroenkul, B. (2017): Cytotoxic assessment of flying barb fish (Esomus metallicus) from a gold mine area with heavy metal contamination. - International Journal of Environmental Studies 74(4): 613-624.

[42] Ngamniyom, A. (2012): Thai ricefish: a potential bio-indicator specis for monitoring freshwater environment pollutions. - Srinakharinwirot Science Journal 28: 207-218.

[43] Oost, R., Beyer, J., Vermeulem, N. P. E. (2003): Fish bioaccumulation and biomarkers in environmental risk assessment: a review. - Environmental Toxicology and Pharmacology 13: 57-149.

[44] Papadimitriou, E. P., Loumbourdis, N. S. (2003): Copper kinetics and hepatic metallothionein levels in the frog Rana ridibunda, after exposure to $\mathrm{CuCl}_{2}$. - Biometals 16(2): 271-277.

[45] Parvez, S., Raisuddin, S. (2005): Protein carbonyls: novel biomarkers of exposure to oxidative stress-inducing pesticides in freshwater fish Channa punctata (Bloch). Environmental Toxicology and Pharmacology 20: 112-117. 
[46] Paul, N., Chakraborty, S., Sengupta, M. (2014): Lead toxicity on non-specific immune mechanisms of freshwater fish Channa punctatus. - Aquatic Toxicology 152: 105-112.

[47] Pereira, L. S., Ribas, J. L. C., Vicari, T. (2016): Effects of ecologically relevant concentrations of cadmium in a fresh water fish. - Ecotoxicology and Environmental Safety 130: 29-36.

[48] Pollution Control Department (PCD) (1994): Surface Water Quality Standards. Notification of the National Environmental Board; No. 8, Ministry of Natural Resources and Environment, Bangkok, Thailand.

[49] Pollution Control Department (PCD) (2004): Soil Quality Standards for Habitat and Agriculture. - Notification of the National Environmental Board; No. 25, Ministry of Natural Resources and Environment, Bangkok, Thailand.

[50] Pollution Control Department (PCD) (2014): Thailand State of Pollution Report 2014. Pollution Control Department, Ministry of Natural Resources, Bangkok, Thailand.

[51] Promsid, P. (2014): Chromosomal aberration assessment of fish in reservoir affected by leachate in municipal landfill. - Master Thesis in Department of Environmental Science, Graduate School, Khon Kaen University, Thailand.

[52] Requena, J. R., Levine, R. L., Stadtman, E. R. (2003): Recent advances in the analysis of oxidized proteins. - Amino Acids 25: 221-226.

[53] Reznick, A. Z., Packer, L. (1994): Oxidative damage to proteins: spectrophotometric method for carbonyl assay. - Methods in Enzymology 233: 357-363.

[54] Robinson, B., Duwig, C., Bolan, N., Kannathasan, M., Saravanan, A. (2003): Up take of arsenic by New Zealand watercress (Lepidium sativum). - Science of the Total Environment 301: 67-73.

[55] Rohlf, F. J. (2009): NTSYSpc: Numerical Taxonomy and Multivariate Analysis Version 2.2. - Applied Biostatistics Inc., New York.

[56] Sanchez, W., Ait-Aissa, S., Palluel, O., Ditche, J. M., Porcher, J. M. (2007): Preliminary investigation of multi-biomarker responses in three-spined stickleback (Gasterosteus aculeatus L.) sampled in contaminated streams. - Ecotoxicology 16(2): 279-287.

[57] Sarun, K. (2004): Analysis of hazardous waste stream in Khon Kaen metropolitan municipality. - Master Thesis in Environmental Engineering, Graduate School, Khon Kaen University, Thailand.

[58] Sevcikova, M., Modra, H., Slaninova, A., Svobodova, Z. (2011): Metals as a cause of oxidative stress in fish: a review. - Veterinarni Medicina 56: 537-546.

[59] Silbergeld, E. K. (2003): Facilitative mechanisms of lead as a carcinogen. - Mutation Research 533(1-2): 121-133.

[60] Skorbiłowicz, E. (2009): Aquatic plants as bioindicators of contamination of upper Narew river and some of its tributaries with heavy metals. - Environmental Protection Engineering 35(1): 65-77.

[61] Sriuttha, M., Tengjaroenkul, B., Intamat, S., Phoonaploy, U., Thanomsangad, P., Neeratanaphan, L. (2017): Cadmium, chromium and lead accumulation in aquatic plants and animals from a municipal landfill. - Human and Ecological Risk Assessment 23(2): 350-363.

[62] Suhartono, E., Triawanti, Yunanto, A., Firdaus, R. T., Iskandar. (2013): Chronic cadmium hepatooxidative in rats: treatment with haruan fish (Channa striata) extract. APCBEE Procedia 5: 441-445.

[63] Talas, Z. S., Orun, I., Ozdemir, I., Erdogan, K., Alkan, A., Yilmaz, I. (2008): Antioxidative role of selenium against the toxic effect of heavy metals $\left(\mathrm{Cd}^{+2}, \mathrm{Cr}^{+3}\right)$ on liver of rainbow trout (Oncorhynchus mykiss, Walbaum 1792). - Fish Physiology and Biochemistry 34(3): 217-222.

[64] Teles, M., Pacheco, M., Santos, M. A. (2005): Physiological and genetic responses of European eel (Anguilla anguilla L.) to short-term chromium or copper exposure-influence of pre-exposure to a PAH-Like compound. - Environmental Toxicology 20(1): 92-99. 
[65] Tengjaroenkul, B., Intamat, S., Thanomsangad, P., Phoonaploy, U., Neeratanaphan, L. (2018): Cytotoxic effect of sodium arsenite on the Nile tilapia (Oreoshromis niloticus) in vivo. - International Journal of Environmental Studies 75(4): 580-591.

[66] Tiwari, K. K., Singh, N. K., Patel, M. P. (2011): Metal contamination of soil and translocation in vegetables growing under industrial wastewater irrigated agricultural field of Vadodara, Gujarat, India. - Ecotoxicology and Environmental Safety 74: 16701677.

[67] US Environmental Protection Agency (USEPA) (2000): Bioaccumulation Testing and Interpretation for the Purpose of Sediment Quality Assessment. - Bioaccumulation Analysis Workgroup, US Environmental Protection Agency, Washington, DC.

[68] Velma, V., Tchounwou, P. B. (2013): Oxidative stress and DNA damage induced by chromium in liver and kidney of goldfish, Carassius aurata. - Biomarker Insights 8(8): 43-51.

[69] Vilela, C. L. S., Bassin, J. P., Peixoto, R. S. (2018): Water contamination by endocrine disruptors: Impacts, microbiological aspects and trends for environmental protection. Environmental Pollution 235: 546-559.

[70] Vlahogianni, T., Dassenakis, M., Scoullos, M. J., Valavanidis, A. (2007): Integrated use of biomarkers (superoxide dismutase, catalase and lipid peroxidation) in mussels Mytilus galloprovincialis for assessing heavy metals pollution in coastal areas from the Saronikos Gulf of Greece. - Marine Pollution Bulletin 54: 1361-1371.

[71] Waalkes, M. P. (2003): Cadmium carcinogenesis. - Mutation Research 533: 107-120.

[72] Wachirawongsakorn, P., Sangyoka, S. (2013): Assessment of heavy metal distribution in soil and groundwater surrounding municipal solid waste dump site in Nai Muang SubDistrict Administrative Organization, Amphur Phichai, Uttaradit. - Naresuan University Journal: Science and Technology 10(1): 18-29.

[73] Webb, D. (2011): Freshwater shrimp (Palaemonetes australis) as a potential bioindicator of crustacean health. - Environmental Monitoring and Assessment 178(1-4): 537-544.

[74] Wilhelm, F. D. (1996): Fish antioxidant defences -a comparative approach. - Brazilian Journal of Medical and Biological Research 29: 1735-1742.

[75] Wise, S. S., Holmes, A. L., Wish, J. P. (2008): Hexavalent chromium-induced DNA damage and repair mechanisms. - Reviews on Environmental Health 23(1): 39-57.

[76] Wood, R. D., Mitchell, M., Srouros, J., Lindahi, T. (2001): Human DNA repair genes. Science 291: 1284-1289. 